\title{
Evolution of placental structure and function in ruminants
}

\author{
Anthony M. Carter \\ Cardiovascular and Renal Research, Institute of Molecular Medicine, University of Southern Denmark, \\ J.B. Winsloews Vej 21, DK-5000 Odense, Denmark
}

\begin{abstract}
Summary
The defining feature of ruminant placentation is the fusion of binucleate trophoblast cells with uterine epithelium. It was present in the last common ancestor of ruminants and the fusion process is facilitated by the products of endogenous retroviral genes called syncytins. It provides a mechanism to transfer placental hormones to maternal tissues. One of these hormones is placental lactogen, which likewise was present in the ancestral ruminant. An innovation in the pecoran lineage was the placentome, which enabled the exchange area to be increased compared with the diffuse placenta of chevrotains. Duplication of a hemoglobin gene and evolution of a fetal hemoglobin to improve oxygen transfer probably occurred later. Other gene duplications enabled elaboration of the endocrine repertoire of the placenta and occurred at various stages in the evolution of ruminants. The binucleate trophoblast cells express MHC Class I antigens and can be expected to elicit a maternal immune response. A balance needs to be established whereby the semiallogeneic trophoblast is tolerated whilst maintaining vigilance against infection. Uterine macrophages develop along a pathway where they become immunosuppressive, whereas lymphocytes in the uterine epithelium between placentomes remain primed to respond to pathogens. It cannot be determined how such responses evolved, however, due to the paucity of information on the immune system of the uterus in ruminants and other artiodactyls.
\end{abstract}

\section{Introduction}

The mammalian phylogenetic tree provides a scaffold to view the likely path of placental evolution. Epitheliochorial placentation was present in the common ancestor of Cetartiodactyla (artiodactyls including whales) and three other orders (Vogel 2005; Mess \& Carter 2007; Elliot \& Crespi 2009). Here the focus will be on the further evolution of placental structure and function in the ruminant lineage. Where relevant, placentation in ruminants will be compared to that in other artiodactyls. In some instances, however, it is instructive to discuss characters that have 
been subject to convergent evolution in ruminants and more distantly related mammals. This applies in particular to the endocrine functions of the placenta, where there are remarkable parallels between ruminants, rodents and primates.

Current understanding of mammalian evolution derives from analysis of molecular and morphological data. For relationships at the ordinal level and above we defer to two recent papers, one based on molecular data at the family level (Meredith et al. 2011) and the other strong on morphological characters (O'Leary et al. 2013). For relations between families and tribes of ruminants we recommend a recent study (Bibi 2013) that was carefully calibrated by fossil data and based on a mitochondrial genome set (Hassanin et al. 2012). For the most part these trees are congruent. For example, all confirm that chevrotains (Tragulidae) are basal to the five families of pecoran ruminants.

\section{Functional morphology and placental exchange}

Binucleate trophoblast cells

Ruminants have two types of trophoblast. The first forms an epithelium that is in intimate contact with but does not breach the uterine epithelium. The second is the binucleate trophoblast cell (BNC) that is interspersed between the other cells in this epithelium (Fig. 1) and characterized

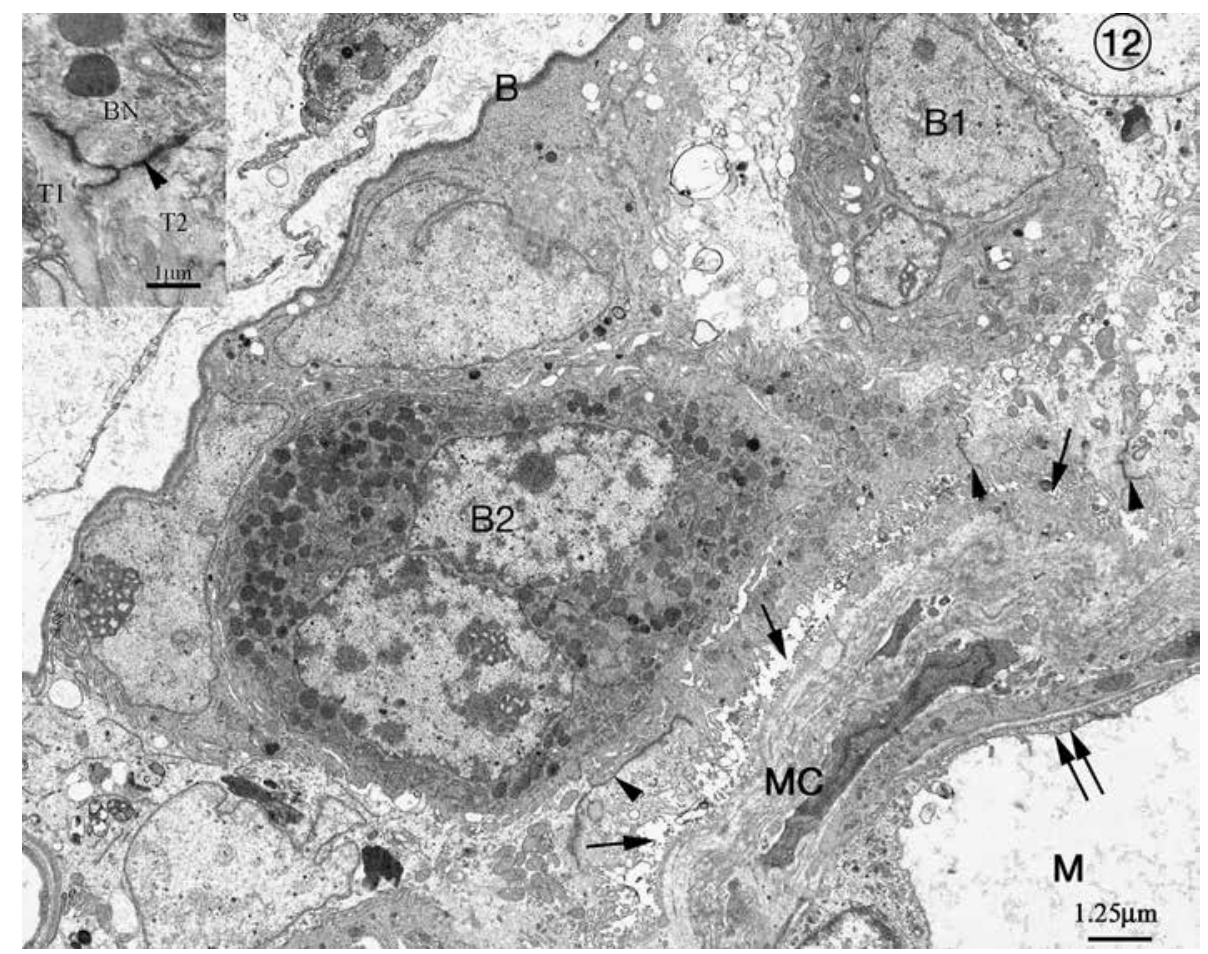

Fig. 1 Early (B1) and late (B2) developmental stages of the binucleate cell in the near term placenta of a chevrotain (Tragulus sp.). Note the difference in shape and electron density from the uninucleate trophoblast cells, which are attached to a basement membrane (B). M, maternal capillary; MC, maternal connective tissue; arrow heads, tight junctions; double arrow, maternal capillary endothelium. Reprinted from Wooding et al. (2007) A light and electron microscopical study of the tragulid (mouse deer) placenta. Placenta 28: 1039-1048, ${ }^{\odot} 2007$ with permission from Elsevier. 
by quite a different repertoire of secreted hormones and cell surface antigen expression. The most remarkable feature of the BNC is its ability to fuse with the uterine epithelium to form either a trinucleate cell, as in the cow, or a more extensive syncytial plaque, as in the sheep and chevrotain (Wooding 1992; Wooding et al. 2007). This type of cell is not found in other mammals and seems to have evolved as a means of delivering fetal hormones to the mother.

One step in the evolution of the fusion process has been capture of a retroviral envelope gene, Syncytin-Rum 1, which is expressed by BNCs in bovine and ovine placentas (Cornelis et al. 2013). In retroviruses, the role of the envelope protein is to promote fusion of the viral membrane with the plasma membrane of a host cell. This property is retained by ruminant syncytin and explains how a BNC expressing the protein is able to fuse with a uterine epithelial cell. The gene was shown to be conserved across all higher ruminants (Pecora), but was absent in other orders of mammal (Cornelis et al. 2013). One of the most highly conserved parts of the sequence was the immunosuppressive domain.

It has not been possible to identify the Syncytin-Rum 1 gene in chevrotains, where BNCs play the same role in placental development as in higher ruminants, including the formation of syncytial plaques (Wooding et al. 2007). It is, of course, possible that the primers used failed to pick up the gene because of sequence divergence in the 50 million years since the ancestor of Tragulidae diverged from that of pecoran ruminants (Cornelis et al. 2013).

Expression of a second syncytin-like gene by BNCs has been shown in four species of Bovinae, although not in sheep or goat (Caprinae) (Nakaya et al. 2013). It was suggested that this gene, named Fematrin-1, could account for the formation of trinucleate cells in bovines as opposed to syncytial plaques in caprines and other ruminants (Nakaya et al. 2013). Independent capture of retroviral envelope genes, resulting in multiple syncytins, is known from other orders of mammal (Dupressoir et al. 2012).

Another group of retroviruses plays a role in differentiation of BNCs in sheep and goats, although not in cattle. These endogenous retroviruses are related to the pathogenic Jaagsiekte sheep retrovirus (JSRV). Five of them are capable of transcription and all have an envelope gene. They are expressed during blastocyst elongation, when differentiation of BNCs first occurs, and later in BNCs and syncytial plaques (Spencer \& Palmarini 2012). A functional role for endogenous JSRVs was demonstrated using antisense oligonucleotides to block JSRV protein production; this inhibited BNC differentiation at the blastocyst stage (Dunlap et al. 2006). A role for endogenous JSRVs in cell fusion has yet to be demonstrated, but it is fair to regard them at least as nascent syncytins (Cornelis et al. 2013).

\section{Caruncles, cotyledons and placentomes}

The most striking feature of pecoran placentation is the presence of multiple placentomes (Andresen 1927). They develop where the chorion overlays the uterine caruncles. The fetal component of a placentome is the cotyledon, but the term frequently is used to refer to the complete structure (Wooding \& Burton 2008). The common ancestor of pecorans had a uterus with four rows of caruncles in each horn and a large number of placentomes ("polycotyledonary placentation"). Reduction to a single row of caruncles and fewer placentomes ("oligocotyledonary placentation") was a later development in the lineages of deer and musk deer (Klisch \& Mess 2007). Meanwhile, greater complexity in the internal folding of the fetal villi evolved in reindeeer (Hamilton et al. 1960) and among the bovids (Hradecky 1986; Hradecky et al. 1988). It is reflected in the increased complexity of vessel branching on the fetal and maternal sides of the placentome. In the sheep, capillary branching increases across gestation and doubtless supports a steady increase in the supply of oxygen and nutrients to the fetus (Reynolds et al. 2010). 
Placental exchange

Sheep have long been the model of choice in fetal physiology (Carter 2011). Therefore a great deal is known about placental transfer of respiratory gases (Longo 1987; Carter 1989), sugars (Hay, Jr. et al. 1990) and amino acids (Battaglia \& Meschia 1978) in ruminants.

One factor promoting placental oxygen transfer is the greater oxygen affinity of fetal hemoglobin. In catarrhine primates this was achieved by duplication of the HBG gene with HBG-T2 serving as the beta chain in fetal hemoglobin. Ruminants have lost the $H B G$ gene (Opazo et al. 2008) Instead there have been two rounds of duplication of the $H B B$ gene. This example of convergent evolution is all the more interesting because a distinct fetal hemoglobin does not occur in any non-ruminant family of Cetartiodactyla. The first duplication of $H B B$ was present in the common ancestor of goats, sheep and cattle (Schimenti \& Duncan 1984). It likely occurred early in the ruminant lineage since a fetal hemoglobin is known to be present in a cervid, the white-tailed deer (Odocoileus virginianus) (Kitchen \& Brett 1974). A second duplication yielding four sets of globin genes occurred in the lineage of sheep and goat (Lingrel et al. 1985; Townes et al. 1984). Thus HBB-2 serves as the beta-chain in the fetal hemoglobin of cattle and HBB-T3 in that of sheep and goat.

Placental transfer of sugars is facilitated by the transporters GLUT1 and GLUT3. In sheep GLUT1 is expressed on the basal membranes of the trophoblast and the maternal syncytium, whereas GLUT3 is localized to the apical surface of the trophoblast (Wooding et al. 2005a). The same pattern occurs in the red deer (Cervus elephas) and goat (Wooding et al. 2005a). These transporters play a similar part in the diffuse placenta of Tragulus, but there is the additional detail that GLUT1 protein is associated with granules within the binucleate cells. This raises the interesting possibility that transporter molecules are delivered from the fetal to the maternal side (Wooding et al. 2014).

A substantial amount of glucose is converted in the placenta to fructose, which is found at high concentrations in the fetal plasma of ruminants, pigs and whales (Cetartiodactyla) as well as horses (Perissodactyla) (Goodwin 1956) and by inference in their common ancestor. In the fetal pig (a non-ruminant) fructose is metabolized via the hexosamine pathway (Kim et al. 2012).

Whilst epitheliochorial placentation does not constitute a barrier to transfer of oxygen and nutrients, special arrangements are required for the transfer of some minerals. The uptake by specialized trophoblast of uterine gland secretions, cell debris or maternal red blood cells is known as histotrophic nutrition. Many ruminants have hemophagous regions within the cotyledons designed for endocytosis and digestion of red cells to supply the fetus with iron (Burton 1982). Iron may also be supplied in uterine gland secretions in the form of uteroferrin as recently described for the water buffalo (Bubalus bubalis) (Pereira et al. 2009). The glandular secretions, often referred to as uterine milk, are absorbed by areolar trophoblast above the gland openings. The areolae seem also to be important for calcium transport as the areolar trophoblast has particularly strong expression of the 9 kilodalton calcium-binding protein (9-CBP) in both Tragulus and the sheep. In addition, 9-CBP is expressed by uninucleate trophoblast cells in the diffuse placenta of Tragulus and the interplacentomal areas of sheep, whereas it is absent from the sheep placentome (Wooding et al. 1996; Wooding et al. 2014).

\section{Endocrinology}

Ruminant placentas secrete an impressive array of hormones (Table 1). Some of these act on the uterine glands. In sheep, where this has best been studied, the glands mature under the influence of maternal steroids and the sequential action of interferon-tau (IFN- $\tau$ ), ovine 
placental lactogen and ovine growth hormone from the trophoblast (Noel et al. 2003). The placenta synthesizes steroid hormones and a wide range of cytokines, but the emphasis here will be on peptide hormones. Each of these has arisen through gene duplication, although at different points in evolution.

Table 1 Peptide hormones secreted by the placenta of ruminants

\begin{tabular}{llll}
\hline Hormone & Distribution & Derivation & Evolution \\
\hline $\begin{array}{l}\text { Interferon- } \tau \text { (IFNT) } \\
\begin{array}{l}\text { Placental lactogens and } \\
\text { prolactin-like proteins }\end{array}\end{array}$ & Pecoran ruminants & Interferon- $\omega($ IFNW) & Gene duplication \\
& & Prolactin $(P R L)$ & $\begin{array}{l}\text { Tandem duplication in } \\
\text { cattle, sheep and goat to } \\
\text { yield multiple genes }\end{array}$ \\
$\begin{array}{lll}\text { Placental growth hormone } \\
\begin{array}{l}\text { Pregnancy-associated } \\
\text { glycoproteins }\end{array}\end{array}$ & Sheep and goat & Growth hormone $(G H)$ & $\begin{array}{l}\text { Gene duplication } \\
\end{array}$ \\
& & An aspartic proteinase & $\begin{array}{l}\text { Ancient and recent genes, } \\
\text { the latter from a second } \\
\text { round of gene duplication } \\
\text { in ruminants }\end{array}$ \\
\hline
\end{tabular}

\section{Interferons}

IFNT, the gene coding for IFN- $\tau$, arose in the pecoran lineage through duplication of IFNW, which codes for interferon-omega (IFN- $\omega$ ) (Roberts et al. 1998; Roberts et al. 2003). IFN- $\tau$ is secreted by trophoblast at the blastocyst stage and its principal function is maintenance of pregnancy. It acts by binding to receptors in the endometrium and suppressing pulsatile secretion of the luteolytic factor prostaglandin $\mathrm{F}_{2 \alpha}$ (Han et al. 1997). This is achieved indirectly by silencing estrogen receptor alpha, thereby reducing expression of oxytocin receptor and thus the oxytocin-induced pulsatility of prostaglandin $\mathrm{F}_{2 \alpha}$ secretion (Fleming et al. 2006).

\section{Placental lactogens}

Placental lactogen evolved following duplication of the prolactin gene $(P R L)$ (Forsyth \& Wallis 2002). The gene is expressed in the binucleate trophoblast cells. Based on an immunostaining protocol, it is present in Tragulus; thus placental lactogen is common to all ruminants (Wooding et al. 1992). However, while some ruminants have a single placental lactogen, there has been tandem duplication in cattle, which have 13 PRL-like genes (Larson et al. 2006; Ushizawa et al. 2005), and in the sheep and goat (Ushizawa et al. 2007b; Ushizawa et al. 2007a). Tandem duplication of the $P R L$ gene as the basis for placental hormones is also known from murid rodents (Forsyth \& Wallis 2002). This is yet another interesting example of convergent evolution.

Placental lactogen binds to receptors in the uterine glands (homodimers of prolactin receptor and heterodimers of prolactin and growth hormone receptors) to stimulate hyperplasia (Noel et al. 2003). In addition, it plays a subsidiary role in maintenance of the corpus luteum (Buttle 1978). It appears not to play any significant role in mammary gland development or lactation (Bassett et al. 1998). Although ovine placental lactogen is an agonist at the prolactin receptor, it acts as an antagonist at the growth hormone receptor (Herman et al. 1999), causing speculation that the placental lactogens of ruminants are players in maternal-fetal conflict over partition of nutrient resources (Haig 2008).

The other PRL-like genes in cattle, sheep and goat code for prolactin-like proteins (PRPs). Most are expressed in binucleate cells but their receptor has not been identified and their function remains obscure. 


\section{Placental growth hormone}

In sheep and goat there is duplication of the growth hormone gene $(G H)$ (Wallis et al. 1998). Clearly this has occurred in the lineage of subfamily Caprinae, since there is only a single $\mathrm{GH}$ gene in cattle (Gootwine 2004). Ovine placenta expresses the pituitary $\mathrm{GH}$ gene as well as that of placental growth hormone (GH2-Z) (Lacroix et al. 1996; Wallis et al. 1998). Ovine placental growth hormone is secreted for a limited period (35-70 days gestation) (Lacroix et al. 1996), but acts synergistically with placental lactogen to promote the uterine gland hypertrophy within this time frame (Noel et al. 2003).

\section{Pregnancy-associated glycoproteins}

Pregnancy-associated glycoproteins (PAGs) make up a family of genes that appeared in Cetartiodactyla and continued to evolve in ruminants (Szafranska et al. 2006; Hughes et al. 2000). PAGs belong to a wider family of aspartic peptidases and have undergone two rounds of gene duplication. The products of the first round, called "ancient PAGs," generally retain the active site (Brandt et al. 2007). In pig and cow, they are expressed at the microvillous junction between the uterine epithelium and trophoblast (Wooding et al. 2005b). Here they may function as linking molecules and play a role in fetal-maternal anchorage.

The second round of duplication was restricted to the ruminant lineage. In cattle, many of the resultant gene products lack the active site of the enzyme, although this is retained in two recent PAGs from the white-tailed deer (Brandt et al. 2007). In general, the recent PAGs are expressed predominantly on the surface of binucleate cells, although deer PAG-3 also is expressed by the mononucleate trophoblast cells (Brandt et al. 2007; Wooding et al. 2005b). Gene duplication is often associated with the assumption of new functions, and it has been suggested that the PAGs expressed on binucleate cells engage in immunological camouflage and facilitate maternal tolerance of this invasive type of trophoblast (Wooding et al. 2005b).

\section{Immunology}

The placenta is a semi-allogeneic transplant and some of the antigens expressed on the surface of trophoblast are paternal in origin. Yet the placenta is not rejected by the maternal immune system. One advantage of epitheliochorial placentation may be that trophoblast encounters only the uterine epithelium. Thus, in relation to the immune system, the placenta has a status comparable to that of a commensal organism in the gut (Moffett \& Loke 2006). This potential advantage is sacrificed in ruminants because BNCs express MHA Class I antigens (Bainbridge et al. 2001) and are in close contact with maternal tissues. There needs to be some degree of immunosuppression, therefore, but this requires a delicate balance as vigilance against infection must be maintained.

The implications for the immune system are difficult to dissect from an evolutionary standpoint because so few species of ruminants and non-ruminant artiodactyls have been looked into. Indeed, information is sparse even for domesticated species. Regulatory T-cells and natural killer cells play a prominent role in the endometrium and decidua of rodents, primates and possibly horses (De Mestre A. et al. 2010), but no recent and reliable information is available on their presence or absence in the ruminant endometrium. CD4 ${ }^{+}$T-cells, CD21 ${ }^{+}$B cells and CD $14^{+}$ macrophages are found in the subepithelial layer of non-pregnant cows and their number and distribution is unchanged during blastocyst elongation in early pregnancy (Leung et al. 2000). 
Immune cells tend to be excluded from the placentomes following implantation, but this has not been studied systematically. There has been greater focus on intraepithelial T-cells and macrophages, which are localized mainly to the interplacentomal regions.

\section{Intraepithelial T-cells}

The ovine uterus has a sizeable population of intraepithelial lymphocytes. From around 50 days of gestation, most of the intraepithelial lymphocytes in the interplacentomal regions are $\gamma \delta T$ cell receptor positive $\left(\gamma \delta \mathrm{TCR}^{+}\right)$cells (Meeusen et al. 1993; Fox et al. 2010). These are large, granular lymphocytes whose granules contain perforin and granulysin (Fox et al. 2010). They are fully differentiated and may play a defensive role toward invading pathogens. Interestingly, $\gamma \delta \mathrm{TCR}^{+}$cells, which are large granular lymphocytes, are largely excluded from the placentomes in both sheep and cow (Lee et al. 1997; Gogolin-Ewens et al. 1989). In contrast, large granular lymphocytes occur within the placentomes of deer (Cervidae). Indeed, in a study comprising six species of deer (Lee et al. 1995), large granular lymphocytes were closely associated with degranulating trinucleate cells.

\section{Macrophages and dendritic cells}

The endometrial stroma of ruminants contains macrophages. These have been studied most closely in bovine pregnancy. These immune cells are abundant in the interplacentomal regions but occur in lesser numbers within the placentomes (Oliveira \& Hansen 2009). Moreover, macrophages in these two locations differ in expression of CD11b and major histocompatibility complex (MHC) class II markers (Oliveira \& Hansen 2009).

There is a fundamental difference between the transcriptomes of circulating and endometrial macrophages (Oliveira et al. 2010). Evidence suggests that bovine endometrial macrophages differentiate along the M2 pathway, which would endow them with immunosuppressive properties.

Dendritic cells accumulate in the endometrial stroma early in bovine pregnancy. Like macrophages, they have been ascribed an immunomodulatory role (Mansouri-Attia et al. 2012).

\section{Synthesis and conclusions}

The sequence of events in evolution of ruminant placentation is shown in Table 2. It starts with the evolution of epitheliochorial placentation in the common ancestor of the four orders constituting the clade Fereuungulata. Increased placental conversion of glucose to fructose likely arose in the common ancestor of artiodactyls (including ruminants) and perissodactyls (horses and their kin).

The defining feature of ruminant placentation is the binucleate cell and its ability to fuse with uterine epithelial cells to form a syncytium or a trinucleate cell. BNCs can be dated to the last common ancestor of the chevrotains and pecoran ruminants (Table 2). It seems likely that the fusion process was aided by an endogenous retroviral gene. This may have been an antecedent of Syncytin-Rum 1 found in pecorans or represent an independent gene capture. Multiple independent captures of retroviral envelope genes are known from other taxa (Dupressoir et al. 2012). Indeed there is a second syncytin, Fematrin-1, that appears in the lineage of the bovine subfamily (Nakaya et al. 2013) whilst multiple endogenous RJSV genes occur in the caprine subfamily. 
Table 2 Timeline of placental evolution in ruminants, showing the appearance of distinct characters in various taxonomic clades.

\begin{tabular}{|c|c|c|c|c|}
\hline $\begin{array}{l}\text { Taxonomic } \\
\text { clade }\end{array}$ & $\begin{array}{l}\text { Branching point } \\
\text { (mya) }\end{array}$ & $\begin{array}{l}\text { Geological } \\
\text { period }\end{array}$ & Character & Comments \\
\hline Fereuungulata & 82.0 & Cretaceous & $\begin{array}{l}\text { Epitheliochorial } \\
\text { placentation }\end{array}$ & $\begin{array}{l}\text { Reversion to } \\
\text { endotheliochorial state in } \\
\text { carnivores }\end{array}$ \\
\hline Euungulata & 66.5 & Cretaceous & $\begin{array}{l}\text { Placental conversion of } \\
\text { glucose to fructose }\end{array}$ & \\
\hline Cetartiodactyla & 65.4 & Paleocene & $\begin{array}{l}\text { Pregnancy-associated } \\
\text { glycoproteins }\end{array}$ & \\
\hline \multirow[t]{2}{*}{ Ruminantia } & 40.3 & Eocene & $\begin{array}{l}\text { Binucleate trophoblast cells } \\
\text { and fusion with uterine } \\
\text { epithelium }\end{array}$ & \\
\hline & & & Placental lactogens & Further elaborated in Bovidae \\
\hline \multirow[t]{3}{*}{ Pecora } & 20.4 & Early Miocene & Placentomes & $\begin{array}{l}\text { Number reduced in Cervidae } \\
\text { and Moschidae }\end{array}$ \\
\hline & & & $\begin{array}{l}\text { Syncytin gene (Syncytin- } \\
\text { Rum1) }\end{array}$ & \\
\hline & & & Interferon-tau gene (IFNT) & \\
\hline Bovidae & 16.2 & Early Miocene & $\begin{array}{l}\text { Duplication of } H B B \text { gene } \\
\text { for high affinity fetal } \\
\text { hemoglobin }\end{array}$ & $\begin{array}{l}\text { May have evolved earlier } \\
\text { since a fetal hemoglobin has } \\
\text { been reported in Cervidae }\end{array}$ \\
\hline Bovinae & 11.0 & $\begin{array}{l}\text { Middle } \\
\text { Miocene }\end{array}$ & Syncytin gene (Fematrin-1) & \\
\hline \multirow[t]{2}{*}{ Caprinae } & 10.1 & $\begin{array}{l}\text { Middle } \\
\text { Miocene }\end{array}$ & $\begin{array}{l}\text { Endogenous JSRV retroviral } \\
\text { genes }\end{array}$ & \\
\hline & & & Placental growth hormone & \\
\hline
\end{tabular}

Approximate dates (million years ago, mya) above the family level are taken from Meredith et al. (Meredith et al. 2011) and for families and subfamilies from Bibi (Bibi 2013). Fereuungulata comprises the orders Perissodactyla, Pholidota, Carnivora and Cetartiodactyla.

From a functional standpoint, fusion of BNCs and epithelial cells facilitates delivery to the maternal tissues of cytokines and hormones made in the BNC. Placental lactogen is the best known signal. It is already present in chevrotains and acts to enhance uterine gland secretion and nourishment of the embryo with histotroph. PAGs, which had evolved in the artiodactyl lineage, underwent further elaboration in the ruminants, where many are expressed by BNCs.

The next major event in ruminants was the evolution of placentomes. The common ancestor of extant pecorans had four rows of caruncles in each uterine horn and a large number of placentomes. Placentomes greatly increase the exchange area of the placenta (Baur 1977) and may have been a necessary adaptation to ensure an adequate supply of substrates to the fetus (Klisch \& Mess 2007). Reduction to a single row of caruncles and far fewer but larger placentomes occurred later in the lineages of deer (Cervidae) and musk deer (Moschidae).

Another innovation in pecorans was duplication of the IFNW gene to yield IFNT and secretion of interferon- $\tau$ by the trophectoderm of the elongating blastocyst. IFN- $\tau$ binds to receptors in the endometrium and suppresses pulsatile secretion of the luteolytic factor $\mathrm{PGF}_{2 \alpha}$ (Han et al. 1997; Fleming et al. 2006). It is pertinent to ask how this is achieved in chevrotains, but very little is known about their reproductive biology (Kusuda et al. 2013). Maybe another cytokine performs 
a similar function, perhaps even interferon- $\omega$. Alternatively, the luteotrophic action of placental lactogen could be sufficient to support luteal function as shown for the hypophysectomized goat (Buttle 1978).

Bovidae is the largest ruminant order by far with $>140$ species (Wilson \& Reeder 2005). Apart from further elaboration of prolactin-like proteins and PAGs, this family is distinguished by duplication of the $H B B$ gene yielding the beta globin component ("gamma chain") of fetal hemoglobin. Innovations at the subfamily level include Fematrin-1 in bovines and enRJSVs and placental growth hormone in sheep and goats (Table 2).

It would be fascinating to follow the response of the maternal immune system to such innovations as BNCs and placentomes. Unfortunately too little information is available for ruminants and non-ruminants alike to place this in an evolutionary context.

One can only guess at the selection pressures driving placental evolution. Recognition that epitheliochorial placentation evolved from a more invasive type is of recent date (Vogel 2005; Mess \& Carter 2007) and the perceived advantage of isolating the fetal allograft from the maternal immune system (Moffett \& Loke 2006) is difficult to substantiate. This is particularly the case because the most successful groups have abandoned a strict separation of maternal and fetal tissues. In horses, trophoblast girdle cells invade the uterus to form hormone-secreting endometrial cups and elicit an immune response (De Mestre A. et al. 2010). In ruminants BNCs fuse with uterine epithelial cells as a means to secreting hormones to the maternal system. For mammals as a whole there are numerous instances of convergent evolution (Carter 2012). One example is the evolution in ruminants and primates of fetal haemoglobins with high oxygen affinity. Another is the emergence of different mechanisms to maintain luteal function exemplified in ruminants by IFNT. Care must be taken in extrapolating from ruminants to phylogenetically distant groups, such as primates, and their validity as animal models assessed on a case to case basis. Elsewhere (Carter 2007) it is argued that the sheep is a useful model for studies of placental gas transfer. In contrast, placental lactogens evolved convergently in ruminants and primates through duplication of different genes and it is hazardous to extrapolate from one to the other. Comparative studies are of greatest utility when adequately informed by phylogenetics.

\section{References}

Andresen A 1927 Die Plazentome der Wiederkäuer. Morphol Jahrb 57 410-485.

Bainbridge DR, Sargent IL \& Ellis SA 2001 Increased expression of major histocompatibility complex (MHC) class I transplantation antigens in bovine trophoblast cells before fusion with maternal cells. Reproduction. 122 907-913.

Bassett NS, Currie MJ, Breier BH, Klempt M, Min SH, McCutcheon SN, MacKenzie DD \& Gluckman PD 1998 The effects of ovine placental lactogen and bovine growth hormone on hepatic and mammary gene expression in lactating sheep. Growth Horm.IGF.Res. 8 439-446.

Battaglia FC \& Meschia G 1978 Principal substrates of fetal metabolism. Physiol Rev. 58 499-527.

Baur R 1977 Morphometry of the placental exchange area. Adv.Anat Embryol.Cell Biol 53 3-65.

Bibi F 2013 A multi-calibrated mitochondrial phylogeny of extant Bovidae (Artiodactyla, Ruminantia) and the importance of the fossil record to systematics. BMC. Evol.Biol 13166.
Brandt GA, Parks TE, Killian G, Ealy AD \& Green JA 2007 A cloning and expression analysis of pregnancy-associated glycoproteins expressed in trophoblasts of the white-tail deer placenta. Mol.Reprod.Dev. 74 1355-1362.

Burton GJ 1982 Review article. Placental uptake of maternal erythrocytes: a comparative study. Placenta 3 407-434.

Buttle HL 1978 The maintenance of pregnancy in hypophysectomized goats. J.Reprod.Fertil. 52 255-260.

Carter AM 1989 Factors affecting gas transfer across the placenta and the oxygen supply to the fetus. J.Dev.Physiol 12 305-322.

Carter AM 2007 Animal models of human placentation-a review. Placenta 28 Suppl A S41-S47.

Carter AM 2011 Animal models of female reproduction and fetal growth and development. In Handbook of Laboratory Animal Science Volume II Animal Models, pp. 237-254. Eds J Hau \& SJ Schapiro. Boca Raton: CRC Press.

Carter AM 2012 Evolution of placental function in mammals: the molecular basis of gas and nutrient 
transfer, hormone secretion, and immune responses. Physiol Rev. 92 1543-1576.

Cornelis G, Heidmann O, Degrelle SA, Vernochet C, Lavialle $C$, Letzelter $C$, Bernard-Stoecklin S, Hassanin A, Mulot B, Guillomot M, Hue I, Heidmann T \& Dupressoir A 2013 Captured retroviral envelope syncytin gene associated with the unique placental structure of higher ruminants. Proc Natl.Acad.Sci.U.S.A 110 E828-E837.

De Mestre A., Noronha L, Wagner B \& Antczak DF 2010 Split immunological tolerance to trophoblast. Int.J.Dev. Biol 54 445-455.

Dunlap KA, Palmarini M, Varela M, Burghardt RC, Hayashi K, Farmer JL \& Spencer TE 2006 Endogenous retroviruses regulate periimplantation placental growth and differentiation. Proc.Natl.Acad.Sci.U.S.A 103 14390-14395.

Dupressoir A, Lavialle C \& Heidmann T 2012 From ancestral infectious retroviruses to bona fide cellular genes: role of the captured syncytins in placentation. Placenta 33 663-671.

Elliot MG \& Crespi BJ 2009 Phylogenetic evidence for early hemochorial placentation in eutheria. Placenta 30 949-967.

Fleming JG, Spencer TE, Safe SH \& Bazer FW 2006 Estrogen regulates transcription of the ovine oxytocin receptor gene through GC-rich SP1 promoter elements. Endocrinology 147 899-911.

Forsyth IA \& Wallis M 2002 Growth hormone and prolactin--molecular and functional evolution. J.Mammary.Gland.Biol.Neoplasia. 7 291-312.

Fox A, Maddox JF, de Veer MJ \& Meeusen EN 2010 GammadeltaTCR + cells of the pregnant ovine uterus express variable $\mathrm{T}$ cell receptors and contain granulysin. J.Reprod.Immunol. 84 52-56.

Gogolin-Ewens KJ, Lee CS, Mercer WR \& Brandon MR 1989 Site-directed differences in the immune response to the fetus. Immunology 66 312-317.

Goodwin RF 1956 Division of the common mammals into two groups according to the concentration of fructose in the blood of the foetus. J.Physiol 132 146-156.

Gootwine E 2004 Placental hormones and fetal-placental development. Anim Reprod.Sci. 82-83 551-566.

Haig D 2008 Placental growth hormone-related proteins and prolactin-related proteins. Placenta 29 Suppl A S36-S41.

Hamilton WJ, Harrion RJ \& Young BA 1960 Aspects of placentation in certain cervidae. J Anat 94 1-33.

Han CS, Mathialagan N, Klemann SW \& Roberts RM 1997 Molecular cloning of ovine and bovine type I interferon receptor subunits from uteri, and endometrial expression of messenger ribonucleic acid for ovine receptors during the estrous cycle and pregnancy. Endocrinology 138 4757-4767.

Hassanin A, Delsuc F, Ropiquet A, Hammer C, Jansen v, V, Matthee C, Ruiz-Garcia M, Catzeflis F, Areskoug V, Nguyen TT \& Couloux A 2012 Pattern and timing of diversification of Cetartiodactyla (Mammalia, Laurasiatheria), as revealed by a comprehensive analysis of mitochondrial genomes. C.R Biol 335 32-50.
Hay WW, Jr., Molina RA, DiGiacomo JE \& Meschia G 1990 Model of placental glucose consumption and glucose transfer. Am J.Physiol 258 R569-R577.

Herman A, Helman D, Livnah O \& Gertler A 1999 Ruminant placental lactogens act as antagonists to homologous growth hormone receptors and as agonists to human or rabbit growth hormone receptors. J.Biol.Chem. 274 7631-7639.

Hradecky, P. Comparative histological study of ruminant placentomes. 1986. College Station, Texas, U.S.A., Texas A\&M University.

Hradecky P, Mossman HW \& Stott GG 1988 Comparative histology of antelope placentomes. Theriogenology $\mathbf{2 9}$ 693-714.

Hughes AL, Green JA, Garbayo JM \& Roberts RM 2000 Adaptive diversification within a large family of recently duplicated, placentally expressed genes. Proc.Natl.Acad. Sci.U.S.A 97 3319-3323.

Kim J, Song G, Wu G \& Bazer FW 2012 Functional roles of fructose. Proc.Natl.Acad.Sci.U.S.A 109 E1619-E1628.

Kitchen H \& Brett I 1974 Embryonic and fetal hemoglobin in animals. Ann.N.Y.Acad.Sci. 241 653-671.

Klisch K \& Mess A 2007 Evolutionary differentiation of Cetartiodactyl placentae in the light of the viviparitydriven conflict hypothesis. Placenta 28 353-360.

Kusuda S, Adachi I, Fujioka K, Nakamura M, AmanoHanzawa N, Goto N, Furuhashi S \& Doi O 2013 Reproductive characteristics of female lesser mouse deers (Tragulus javanicus) based on fecal progestagens and breeding records. Anim Reprod.Sci. 137 69-73.

Lacroix MC, Devinoy E, Servely JL, Puissant C \& Kann G 1996 Expression of the growth hormone gene in ovine placenta: detection and cellular localization of the protein. Endocrinology 137 4886-4892.

Larson JH, Kumar CG, Everts RE, Green CA, Everts-van der Wind A, Band MR \& Lewin HA 2006 Discovery of eight novel divergent homologs expressed in cattle placenta. Physiol Genomics 25 405-413.

Lee CS, Wooding FB \& Morgan G 1995 Quantitative analysis of intraepithelial large granular lymphocyte distribution and maternofetal cellular interactions in the synepitheliochorial placenta of the deer. J Anat 187 ( Pt 2) 445-460.

Lee CS, Wooding FB \& Morgan G 1997 Quantitative analysis throughout pregnancy of intraepithelial large granular and non-granular lymphocyte distributions in the synepitheliochorial placenta of the cow. Placenta 18 675-681.

Leung ST, Derecka K, Mann GE, Flint AP \& Wathes DC 2000 Uterine lymphocyte distribution and interleukin expression during early pregnancy in cows. J Reprod. Fertil. 119 25-33.

Lingrel JB, Townes TM, Shapiro SG, Wernke SM, Liberator PA \& Menon AG 1985 Structural organization of the alpha and beta globin loci of the goat. Prog.Clin.Biol. Res. 191 67-79.

Longo LD 1987 Respiratory gas exchange in the placenta. In Handbook of Physiology. Section 3. The Respiratory System. Volume 4. Gas Exchange., pp. 351-401. Eds LE Farhi \& SM Tenney. Bethesda: American Physiological Society. 
Mansouri-Attia N, Oliveira LJ, Forde N, Fahey AG, Browne JA, Roche JF, Sandra O, Reinaud P, Lonergan P \& Fair T 2012 Pivotal role for monocytes/macrophages and dendritic cells in maternal immune response to the developing embryo in cattle. Biol Reprod. 87123.

Meeusen E, Fox A, Brandon M \& Lee CS 1993 Activation of uterine intraepithelial gamma delta $\mathrm{T}$ cell receptorpositive lymphocytes during pregnancy. Eur.J.Immunol. 23 1112-1117.

Meredith RW, Janecka JE, Gatesy J, Ryder OA, Fisher CA, Teeling EC, Goodbla A, Eizirik E, Simao TL, Stadler T, Rabosky DL, Honeycutt RL, Flynn JJ, Ingram CM, Steiner C, Williams TL, Robinson TJ, Burk-Herrick A, Westerman M, Ayoub NA, Springer MS \& Murphy WJ 2011 Impacts of the Cretaceous Terrestrial Revolution and KPg Extinction on Mammal Diversification. Science 334 521-524.

Mess A \& Carter AM 2007 Evolution of the placenta during the early radiation of placental mammals. Comp Biochem.Physiol A Mol.Integr.Physiol 148 769-779.

Moffett A \& Loke C 2006 Immunology of placentation in eutherian mammals. Nat Rev.Immunol. 6 584-594.

Nakaya Y, Koshi K, Nakagawa S, Hashizume K \& Miyazawa T 2013 Fematrin-1 is involved in fetomaternal cell-to-cell fusion in Bovinae placenta and has contributed to diversity of ruminant placentation. J Virol. 87 10563-10572.

Noel S, Herman A, Johnson GA, Gray CA, Stewart MD, Bazer FW, Gertler A \& Spencer TE 2003 Ovine placental lactogen specifically binds to endometrial glands of the ovine uterus. Biol.Reprod. 68 772-780.

O'Leary MA, Bloch JI, Flynn J], Gaudin TJ, Giallombardo A, Giannini NP, Goldberg SL, Kraatz BP, Luo ZX, Meng J, Ni X, Novacek MJ, Perini FA, Randall ZS, Rougier GW, Sargis EJ, Silcox MT, Simmons NB, Spaulding M, Velazco PM, Weksler M, Wible JR \& Cirranello AL 2013 The placental mammal ancestor and the post-K-Pg radiation of placentals. Science 339 662-667.

Oliveira LJ \& Hansen PJ 2009 Phenotypic characterization of macrophages in the endometrium of the pregnant cow. Am J.Reprod.Immunol. 62 418-426.

Oliveira LJ, McClellan S \& Hansen PJ 2010 Differentiation of the endometrial macrophage during pregnancy in the cow. PLoS.One. 5 e13213.

Opazo JC, Hoffmann FG \& Storz JF 2008 Differential loss of embryonic globin genes during the radiation of placental mammals. Proc.Natl.Acad.Sci.U.S.A 105 12950-12955.

Pereira FT, Braga FC, Burioli KC, Kfoury Jr JR, Oliveira L, Papa P, Carvalho AF, Ambrosio CE, Bazer FW \& Miglino MA 2009 Transplacental Transfer of Iron in the Water Buffalo (Bubalus bubalis): Uteroferrin and Erythrophagocytosis. Reprod.Domest.Anim.

Reynolds LP, Borowicz PP, Caton JS, Vonnahme KA, Luther JS, Hammer CJ, Maddock Carlin KR, Grazul-Bilska AT \& Redmer DA 2010 Developmental programming: the concept, large animal models, and the key role of uteroplacental vascular development. J Anim Sci. 88 E61-E72.

Roberts RM, Ezashi T, Rosenfeld CS, Ealy AD \& Kubisch HM 2003 Evolution of the interferon tau genes and their promoters, and maternal-trophoblast interactions in control of their expression. Reprod.Supp/ 61 239-251.
Roberts RM, Liu L, Guo Q, Leaman D \& Bixby J 1998 The evolution of the type I interferons. J.Interferon Cytokine Res. 18 805-816.

Schimenti JC \& Duncan CH 1984 Ruminant globin gene structures suggest an evolutionary role for Alu-type repeats. Nucleic Acids Res. 12 1641-1655.

Spencer TE \& Palmarini M 2012 Endogenous retroviruses of sheep: a model system for understanding physiological adaptation to an evolving ruminant genome. J.Reprod. Dev. 58 33-37.

Szafranska B, Panasiewicz G \& Majewska M 2006 Biodiversity of multiple Pregnancy-Associated Glycoprotein (PAG) family: gene cloning and chorionic protein purification in domestic and wild eutherians (Placentalia)-a review. Reprod.Nutr.Dev. 46 481-502.

Townes TM, Fitzgerald MC \& Lingrel JB 1984 Triplication of a four-gene set during evolution of the goat beta-globin locus produced three genes now expressed differentially during development. Proc Natl.Acad.Sci.U.S.A 81 6589-6593.

Ushizawa K, Takahashi T, Hosoe M, Kaneyama K \& Hashizume K 2005 Cloning and expression of two new prolactin-related proteins, prolactin-related protein-VIII and -IX, in bovine placenta. Reprod.Biol Endocrinol. 368.

Ushizawa K, Takahashi T, Hosoe M, Kizaki K, Abe Y, Sasada H, Sato E \& Hashizume K 2007a Gene expression profiles of novel caprine placental prolactin-related proteins similar to bovine placental prolactin-related proteins. BMC.Dev.Biol 716.

Ushizawa K, Takahashi T, Hosoe M, Ohkoshi K \& Hashizume K 2007b Expression and characterization of novel ovine orthologs of bovine placental prolactinrelated proteins. BMC.Mol.Biol 895.

Vogel P 2005 The current molecular phylogeny of Eutherian mammals challenges previous interpretations of placental evolution. Placenta 26 591-596.

Wallis M, Lioupis A \& Wallis OC 1998 Duplicate growth hormone genes in sheep and goat. J.Mol.Endocrinol. 21 1-5.

Wilson DE \& Reeder DM 2005 Mammal Species of the World. Baltimore: Johns Hopkins University Press.

Wooding FB 1992 Current topic: the synepitheliochorial placenta of ruminants: binucleate cell fusions and hormone production. Placenta 13 101-113.

Wooding FB \& Burton GJ 2008 Comparative Placentation: Structures, Function and Evolution. Berlin: Springer.

Wooding FB, Fowden AL, Bell AW, Ehrhardt RA, Limesand SW \& Hay WW 2005a Localisation of glucose transport in the ruminant placenta: implications for sequential use of transporter isoforms. Placenta 26 626-640.

Wooding FB, Kimura J \& Forhead AJ 2014 Functional immunocytochemistry of Tragulus placenta: implications for ruminant evolution. Placenta $\mathbf{3 5}$.

Wooding FB, Kimura J, Fukuta K \& Forhead AJ 2007 A light and electron microscopical study of the Tragulid (mouse deer) placenta. Placenta 28 1039-1048.

Wooding FB, Morgan G, Forsyth IA, Butcher G, Hutchings A, Billingsley SA \& Gluckman PD 1992 Light and electron microscopic studies of cellular localization of oPL with monoclonal and polyclonal antibodies. J.Histochem. Cytochem. 40 1001-1009. 
Wooding FB, Morgan G, Monaghan S, Hamon M \& Heap RB 1996 Functional specialization in the ruminant placenta: evidence for two populations of fetal binucleate cells of different selective synthetic capacity. Placenta 17 75-86.
Wooding FB, Roberts RM \& Green JA 2005b Light and electron microscope immunocytochemical studies of the distribution of pregnancy associated glycoproteins (PAGs) throughout pregnancy in the cow: possible functional implications. Placenta 26 807-827. 